\title{
Implementing an Interdisciplinary Masters Program in Internet Technology and E-Commerce
}

\author{
Daniel J. Farkas and Narayan Murthy \\ Pace University, Pleasantville, NY, USA
}

dfarkas@pace.edu nmurthy@pace.edu

\begin{abstract}
The explosion of the Internet has lead to a revolutionary way of doing business. Electronic commerce is currently estimated at $\$ 30$ billion, but analysts predict that figure to grow to $\$ 400$ billion by the year 2002. This leads to a tremendous need for skilled personnel who can handle both the technical and business aspects of e-commerce. One magazine article heading reads: "Looking for a New Job? Head for the Web." A recent announcement by U.S. Small Business Administration states that lack of technical expertise and lack of qualified IT employees are two of the major E-Commerce obstacles facing small firms.

Working with the existing administrative infrastructure, Pace University's School of Computer Science and Information Systems has designed an interdisciplinary program, Master of Science in Information Technologies for Electronic Commerce. This short paper is an overview of the M.S. program.
\end{abstract}

\section{Introduction}

The M.S. in IT for EC is an interdisciplinary program, offered by the School of Computer Science and Information Systems. Students take courses in information technology courses from the school of CSIS and business courses from the school of Business.

CSIS offers M.S. degree programs in computer science, information systems and telecommunications. In addition, the school of business offers MBA programs - both traditional and an intense executive program. All our M.S. programs are 36 credit programs. The proposed M.S. in IT for EC is also a 36-credit program but uniquely and creatively draws from the four disciplines mentioned above.

Students deficient in programming and basic business principles will be asked to take prerequisite courses.

\section{Administrative Infrastructure}

Pace University is divided into six schools (liberal arts, business, computer science and information systems, nursing, education and law). Curriculum committees exist within departments, schools and campuses. In addition to getting State approvals for the offering of degrees, it is necessary to get approvals ranging from consensus to formal votes for courses and programs.

Material published as part of these proceedings, either on-line or in print, is copyrighted by Informing Science. Permission to make digital or paper copy of part or all of these works for personal or classroom use is granted without fee provided that the copies are not made or distributed for profit or commercial advantage AND that copies 1) bear this notice in full and 2) give the full citation on the first page. It is permissible to abstract these works so long as credit is given. To copy in all other cases or to republish or to post on a server or to redistribute to lists requires specific permission from the publisher at publister@intormingscience.org
This is especially difficult for interdisciplinary programs and especially problematic for an area of study that is emerging faster than committees typically work. 


\section{Developing the Curriculum}

While the discipline as an academic program is relatively new, Pace University has been involved for many years in the development of technology-enhanced curriculum. The University has a strong commitment and track record in non-credit programs dating back to the middle eighties. As this program was being considered, existing programs included Web programming, business courses, and emerging technologies. An undergraduate certificate in Internet Technology was put into place in the fall of 1999. A graduate certificate is expected for fall 2000.

The design team for non-credit bearing program in E-commerce technology included the two authors of the paper as well as representatives from the University community involved in the development of professional websites including both front and back-end processing.

A guiding objective to the program was that students should understand the context of E commerce in the business and organizational environment and have the technical skills to build and manage websites. That is, understand how to design, build, and manage an online enterprise.

The MS in ITEC takes off from here by providing the student with the insight to make decisions through the process of Online Enterprise management. What is the business problem being solved? How does the Internet fit into the organization's existing strategy or extend it? What tools should be used to develop the site? How should it be monitored, evaluated?

\section{Managing the Development of the Program}

Unlike a truly entrepreneurial organization, the University requires consensus though a number of committees and also requires the development of a financial justification for the program. This includes costs and expected revenue projections. The hard part is getting consensus.

The authors spent the 1999-2000 academic year making presentations to all the curriculum committees involved and anyone else who would listen. Most of the reaction was positive, but there were many objections to different aspects of the program and the curriculum was modified when the comments made sense.

For example, one question had to do with the pre-requisites. If the courses are taken from Computer Science, for example, will computer science and itec students be intermingled? Do both programs have similar prerequisites? This caused the curriculum to be designed such that the courses are not the same as those in either the CS or IS departments. Furthermore, students in this program can only take electives in other departments with either appropriate prerequisites or permission of the Chair.

The key decision for this program was not placing it in an existing department or borrow courses for any department, but rather, have it managed by the Computer Science and Information System Departments. The course prefixes have been changed to uniquely identify the program.

Almost all objections from departmental curriculum committees went away with this decision.

\section{E-commerce or for E-commerce: What's in a word?}

Perhaps the most important difficulty would be incorporating the business curriculum into the program. It was felt that it was necessary for students to understand the context of the technology being employed, not just learning languages and tools. The business school issue had to do with accreditation and their understanding of the definition of E-commerce.

First, the business school under professional accrediting guidelines must manage programs that are at least half business. AACSB issues could arise if the program had too much business in it. The compro- 
mise was to include 6 required credits with room for more electives. This was more that satisfactory to the Dean of CSIS.

Secondly, the Dean of the Business School felt that E-commerce was an emerging business discipline, but would be satisfied if the word "for" was included.

With Computer Science, Information Systems and the Business School in agreement, the proposal could proceed and the program could start.

\section{Distance Education or Face to Face}

Online education; distance education; asynchronous learning - these are all delivery modes that are being encouraged by institutions of higher education as ways to both compete in the market for students, deliver higher quality education, and incorporate the modern world of the Internet into their programs.

Pace University is a leader in delivering both credit bearing and non-credit bearing distance education. We are a leading recipient of grants to develop and deliver online programs and have had significant success in this area. There are a number of different distance models that we use:

- All online, synchronous

- All online, asynchronous

- Online, with scheduled meetings.

- Traditional classroom delivery

It is the intention of CSIS to eventually deliver most if not all of the program online, but we recognize that there are many unresolved issues:

- Learning Styles

- Accreditation

- Assessment

As these problems are addressed and understood, we feel that more of the program will be online. Initially the program will be traditional classroom based with the eye to continue to develop the curriculum for Internet delivery.

\section{The Curriculum}

Number of credits: 36

\section{Degree Requirements}

\section{Credits}

Required Information Technology Courses 12

Required Business Courses 6

Elective Courses 12

Capstone Project 6

Total 36 
Implementing an Interdisciplinary Masters Program

\section{Prerequisite Courses (Maximum 10 credits)}

- CIS 500 Introduction to Internet, Web Authoring and Multimedia (3 credits)

- CS 502 Fundamentals of programming (4 credits)

- BUS 507 Managerial Marketing (3 credits)

\section{Required Information Technology Courses (12 credits):}

- CIS600 Overview of Computer Networks and Internet Technology

- CIS604 Web Development I: JavaScript and CGI Scripts

- CIS608 Web Development II: Java Applets and Java Servlets

- CIS612 Webserver setup, Configuration and Security issues

\section{Business Course Requirements (6 credits) chose 2 of 4:}

- MGT 641 Managing Innovation and Technology

- MGS 632 Supply Chain Management

- MAR 643 E-Marketing

- MAR 645 Advertising

\section{Capstone Course Requirement (6 credits)}

\section{CIS900 E-commerce Project}

Each student develops a practical project under the supervision of a faculty member.

\section{Conclusion}

In conclusion, we see that the development and implementation of the MS in Internet Technology for Ecommerce has been innovative from the "chair's" perspective in several ways:

- Managing conflicting interests and perspectives

- Bringing together participants from several disciplines

- Offering a program on a timely basis

- Staying sensitive to delivery options

\section{References}

Micken, K.S. (2000). Cutting,-Alan-C. Connecting Technology to Teaching and Learning. Connecting @ the Crossroads, NECC 2000: National Educational Computing Conference Proceedings (Atlanta, GA, June 26-28, 2000)

Ormerod, D.E. (1995). Computers across the Curriculum: Teaching a Computer Literacy Course for Multi-Disciplinary Use in a Network Environment--Content and Pedagogy. Association of Small Computer Users in Education (ASCUE) Summer Conference. Proceedings (28th, North Myrtle Beach, South Carolina, June 18-22, 1995)

Zeidler,D.L., LeBaron, J.F. (1997). Meeting the Challenge of Professional Development: Design and Evaluation of a Telecommunications Mediated Course in Science, Mathematics, and Technology Education. Paper presented at the Annual Meeting of the National Association for Research in Science Teaching (70th, Oak Brook, IL, March 21-24, 1997). 


\section{Biographies}

Daniel Farkas has a MS in Computer Science from NYU, and is currently the Chairman of the Information Systems Department at Pace University in New York. He has been teaching for over 25 years both graduate and undergraduate Information Systems and Computer Science courses. Prior to coming to Pace he spent several years designing computer-based financial systems for the banking industry. In addition to publication in academic proceedings, he is the author of two books, data Communications: Concepts, Terms, Definitions, Carnegie Press, 1982 and Unix for Programmers, John Wiley \& Sons, 1988.

Narayan Murthy has a Ph.D. in Mathematics and a MS in Computer Science from University of Rhode Island, RI, USA. He has taught mathematics and computer science for more than 25 years, in India and USA. He is currently professor and chairman of the department of computer science at Pace University in New York. 